Syntax Literate: Jurnal Ilmiah Indonesia p-ISSN: 2541-0849

e-ISSN: 2548-1398

Vol. 5, No. 11, November 2020

\title{
KETERLIBATAN PETUGAS DALAM PEREDARAN NARKOBA DAN PROGRAM PEMBINAAN NARAPIDANA PENGGUNA NARKOBA DI LAPAS
}

\author{
Afifudin Muhammad Yunus \\ Politeknik Ilmu Pemasyarakatan Depok, Jawa Barat, Indonesia \\ Email: yunusmuhammad589@gmail.com
}

\begin{abstract}
This research aims to discover the involvement of correctional officers in drug trafficking at prisons and coaching programs that are applied to drug user inmates. The method used in this paper is a literature study. A method is carried out by quoting from books, journals, magazines, legal literature, and scientific essays, and similar lecture notes that are related to this writing. The results of this paper are how to minimize and prevent drug trafficking, which there is especially interference from correctional officers. Programs for drug users undergoing prisoners in prison include Medical rehabilitation, non-medical rehabilitation, and aftercare rehabilitation. Users and drug dealers are all placed in prison. In this case, the user is a victim and should be rehabilitated in a rehabilitation institution and not sentenced to prison. This can have a negative effect, which was previously a prisoner as a user but associating with dealers so that it will likely get intervention from other prisoners.
\end{abstract}

Keywords: Prisoners; Drugs; Correctional Officers

\begin{abstract}
Abstrak
Penelitian ini bertujuan untuk mengetahui keterlibatan petugas pemasyarakatan dalam peredaran narkoba di dalam lapas serta program pembinaan yang diterapkan kepada narapidana pengguna narkoba. Metode yang digunakan dalam penulisan ini adalah study pustaka. Metode ini dilakukan dengan cara mengutip dari buku, jurnal, majalah, literatur hukum, serta karangan ilmiah dan catatan kuliah yang sejenis dan ada kaitannya dengan penelitian ini. Hasil dari penelitian ini adalah bagaimana meminimalisir dan mencegah peredaran narkoba didalam yang khususnya ada campur tangan dari petugas pemasyarakatan. Program bagi pengguna narkoba yang dijalani narapidana di lembaga pemasyarakatan antara lain: Rehabilitasi medis, rehabilitasi non medis, dan rehabilitasi after care. Pemakai, pengedar, dan bandar semuanya ditempatkan di lapas. Dalam hal ini pemakai adalah korban dan seharusnya direhabilitasi di panti rehabilitasi dan bukan dipidana di lapas. Hal ini dapat menimbulkan efek yang negatif, yang sebelumnya narapidana sebagai pemakai tetapi bergaul dengan pengedar sehingga kemungkinan akan mendapat intervensi dari narapidana lain.
\end{abstract}

Kata kunci: Narapidana; Narkoba; Petugas Pemasyarakatan 


\section{Pendahuluan}

Efek dari penggunaan narkoba atau obat-obatan terlarang bisa merusak kehidupan baik itu keluarga, lingkungan sosialnya. Bahkan secara cepat ataupun lambat, secara langsung maupun tidak langsung akan menjadi acaman besar bagi kelangsungan pembangunan indonesia yang akan datang. Untuk menghadapi berbagai permasalahan penyalahgunaan narkoba dan peredaran gelap narkoba, pemerintah telah mengeluarkan Undang-Undang Nomor 35 Tahun 2009 Tentang Narkotika dan Undang-Undang Nomor 5 Tahun 1997 tentang Psikotropika. Dengan dikeluarkan undang-undang diharapkan kedepannya dapat meminimalisir tindak kejahatan baik penyalahgunaan narkoba ataupun peredaran ilegal narkoba. Karena didalam undang-undang terebut akan dijatuhkan sanksi pidana yang cukup berat apabila dibandingkan dengan undangundang tindak pidana lainnya.

Penyelesaian masalah mengenai peredaran narkoba yang dilakukan oleh pegawai didalam Lembaga Pemasyarakatan perlahan mulai ditangani. Direktur Jenderal Pemasyarakatan Kementerian Hukum dan HAM RI mengatakan bahwa pengawasan lapas Khusus untuk narapidana yang terkena kasus narkotika akan dilakukan pengawasan bersama dengan Badan Narkotika Nasional (BNN) dan Polri dengan menggunakan teknologi yang disertai dengan personel yang berintegritas. Penempatan petugas dengan Assesment dengan memperhatikan pola kerja serta kesejahteraannya dan tingkat jabatan ditingkatkan secara formal harus dengan penanganan pakta integritas. Lapas juga dicanangkan akan dilengkapi dengan sarana dan prasarana melebihi dari lapas biasa yang berbasis teknologi disertai informasi dilengkapi dengan alat alat keamanan seperti e-visitor, x-ray, dan lainnya.dan penarikan petugas petugas yang terindikasi menggunakan atau terkait dengan peredaran Narkoba di dalam lapas (Lestari, 2017). Peningkatan pengawasan juga ditingkatkan dengan pengawasan yang berlapis. Penempatan narapidana kasus narkoba dengan ditempatkan di lapas Khusus Narkotika bisa menekan dan meminimalisir pengendalian peredaran narkoba di dalam Lembaga Pemasyarakatan. Pembatasan pembatasan dan penegakan harus dilakukan untuk memberhentikan peredaran Narkoba di dalam penjara setidaknya meminimalisir (V. H.Situmorang, HAM, R., \& Kav, 2019). Namun apabila hal ini tidak disertai dengan peningkatan integritas dari para pegawai Lembaga Pemasyarakatan, progam apapun yang dicanangkan akan tetap tidak meberikan dampak yang berarti. Pegawai harus mendapatkan pelatihan dan pengarahan terkait dengan tugas dan fungsi yang seharusnya dikerjakan sesuai dengan peraturan yang berlaku. Dengan pengembangan dan pemanfaatan Sumber Daya Manusia yang ada, Kementerian Hukum dan HAM akan mampu merubah penyimpangan dan penyelewengan yang terjadi di dalam Lembaga Pemasyarakatan (Absori \& Rochman, 2015).

Pemerintah dapat merubah sistem dari memidanakan narapidana yang terkena kasus Narkoba dengan melalui merehabilitasi. Memenjarakan bukan merupakan solusi terbaik yang diberikan negara karena dengan teori sistem dan teori kebutuhan didalam Lembaga Pemasyarakatan, narapidana akan melakuakn seribu akal untuk mendapatkan apa yang dia butuhkan meski harus melalui penyimpangan. Terlebih hal ini didukung 
dengan integritas pegawai yang memang mengalami penurunan serta dalam keadaan kritis. Narapidana kasus narkoba yang dipidanakan dapat menyebarkan narkoba kepada narapidana yang tidak memakai narkoba, awalnya dengan kedok coba coba yang akhirnya berdampak menimbulkan ketergantungan. Hal ini menjadi perhatian untuk mendapatkan solusi terbaik dalam setiap pemecahan masalah terkait dengan peredaran narkoba yang masih sering terjadi di dalam Lembaga Pemasyarakatan. Isu ini telah menjadi masalah publik yang sudah dilazimkan oleh masyarakat karena berbagai tindakan dilakukan namun masih tidak memberikan dampak yang sebenarnya. Contoh kasus pengendalian Narkoba dari penjara yang pertama kali diungkapkan adalah dengan terungkapnnya Narapidana yang terbukti mengendalikan Narkoba dari Nusakambangan yang dilakukan oleh Freddy Budiman yang telah dihukum mati pada Juli 2016 (Arifin, 2016).

\section{Metode Penelitian}

Metode yang digunakan dalam penulisan artikel ini adalah study pustaka. Study pustaka dilakukan dengan cara mengutip dari buku, jurnal, majalah, literatur hukum, serta karangan ilmiah dan catatan kuliah yang ada dalam kaitannya dengan jurnal ini. Study kepustakaan juga bisa dengan mempelajari berbagai referensi seperti buku, artikel, peraturan-peraturan yang berlaku serta hasil penelitaian sebelumnya yang terkait yang bertujuan untuk memperoleh landasan teori mengenai permasalahan yang akan diteliti (Supriyadi, 2016).

Dalam study pustaka ada empat ciri-ciri yang perlu diperhatikan, yaitu : pertama, peneliti atau penulis berhadapan secara langsung dengan bacaan, bukan dari pengamatan lansung ke lapangan. Kedua, data pustaka yang bersifat "siap pakai" yang artinya penulis tidak perlu terjun ke lapangan langsung karena peneliti akan berhadapan langsung dengan sumber data yang diperlukan. Ketiga, data pustaka sekunder, arinya penulis mendapat data dari tangan kedua. Keempat, kondisi data pustaka tidak terbatas (Lexy, 2005). Berdasarkan penjelasan tersebut, maka data yang dibutuhkan dalam penelitian ini dilakukan dengan cara menelaah dan mengeksplorasi dari buku, artikel, Peraturan yang berlaku maupun dokumen yang sejenis dengan jurnal penulis buat.

\section{Hasil dan Pembahasan}

\section{A. Keterlibatan Petugas Pemasyarakatan dalam Peredaran Narkoba}

Terkait dengan maraknya peredaran narkoba didalam lapas, konsideran menimbang Undang-Undang Nomor 12 Tahun 1995 Tentang Pemasyarakatan yang menjelaskan bahwa sitem pemasyarakatan yang dilaksanakan di lapas merupakan rangkaian penegakkan hukum di Indonesia yam memiliki tujuan agar narapidana menyadari kesalahan, bisa memperbaiki diri, dan tidak akan mengulangi tindak pidananya sehingga dapat diterima kembali oleh sosialnya, dapat berperan dalam pembangunan nasional, dan dapat kembali hidup sewajarnya selayaknya warga negara yang baik dan bertanggung jawab. 
Sebagai pelaksanaan undang-undang pemasyarakatan, kemudian dikeluarkan Peraturan Menteri Hukum dan HAM Nomor 6 Tahun 2013 tentang Tata Tertib Lembaga Pemasyarakatan dan Rumah Tahanan Negara yang disebutkan pada pasal 4 huruf g. Dalam peraturan tersebut melarang setiap narapidana atau tahanan menyimpan, membuat, membawa, mengedarkan, dan/atau mengkonsumsi narkotika dan/atau prekursor narkotika serta obat-obatan lain yang berbahaya (Vaulamafiroh, 2020).

Peran divisi Pemasyarakatan untuk memantau dan memonitoring terhadap tugas dan fungsi petugas pemasyarakatan yang bersifat statis namun juga bersifat dinamis dan dapat memetakan jaringan narkoba di Lembaga Pemasyarakatan dengan melakukan pencegahan secara dini dan pembinaan yang tepat. Dengan disertai kerjasama dengan pihak Polri dan BNN. Langkah langkah harus dilakukan tahap demi tahap agar terjadi kesinambungan antara narapidana dan pegawai Lembaga Pemasyarakatan supaya tercipta keamanan serta kesesuaian dengan aturan yang berlaku. Terdapat 517 Lembaga Pemasyarakatan dan Rumah Tahanan di seluruh Indonesia yang memiliki daya tampung 123.000 narapidana (Purnamasari, 2017). Pada kenyataannya jumlah narapidana mencapai 236.000 orang bahkan hampir dua kali lipat. Disisi lain jumlah petugas yang belum memadai dengan jumlah narapidana yang dari tahun ketahun mengalami peningkatan secara bertahap, dengan kekurangan tersebut pegawai tidak dapat melakukan pengawasan secara intensif dan terjadwal, dikarenakan adanya agenda kunjungan disertai agenda pembinaan yang meliputi pembinaan kemandirian dan pembinaan spiritual yang masih membutuhkan pendampingan dari pegawai Lembaga Pemasyarakatan. Dengan memahami situasi setiap hari yang terjadi didalam Lembaga Pemasyarakatan narapidan dapat memetakan kapan mereka dapat melakukan hal hal yang menyimpang. Dari pihak Lembaga Pemayarakatan melakukan inspeksi dadakan (sidak) pada hal hal yang tidak ditentukan tujuannya untuk melakukan pembasmian terhadap penyelundupan barang barang terlarang yang tidak sesuai dengan aturan-aturan.

Kecenderungan banyaknya peredaran narkoba di lapas baik secara kualitas ataupun kuantitas patut kita duga karena faktor keamanan yang masih kurang. Hal ini terjadi karena terbatasnya sarana maupun prasarana pendukung serta kurangya integritas dari petugas pemasyarakatan itu sendiri. Begitu mudahnya bisnis narkoba di dalam lapas, tentu saja ada kekuatan tersembunyi yang berada didalam bisnis haram ini (Apriansyah, 2017). Secara logika, tidak mungkin aktivitas bisnis narkoba ini berlangsung secara aman dan mulus. Disinilah perlu adanya usaha dari pemerintah terkhusus jajaran Kementerian Hukum dan HAM lebih menekankan dan membina petugas pemasyarakatan sebelum membina narapidana, hal ini sangat penting guna menanamkan integritas dan meminimalisir peredaran narkoba di dalam lapas.

Undang-Undang Narkotika maupun Undang-Undang Pemasyarakatan dalam hal penegakan hukum bagi petugas lapas yang terbukti terlibat dalam peredaran narkoba di dalam lapas. Tetapi petugas yang terlibat dalam peredaran gelap narkoba 
akan dilakukan pemberian hukuman disiplin sebagaimana yang sudah diungkapkan oleh mantan Dirjen Pemasyarakata, Sihabudin. Beliau mengungkapkan hukuman disiplin tingkat berat telah dijatuhkan kepada petugas yang terlibat peredaran narkoba didalam lapas.

\section{B. Program Pembinaan Narapidana Narkoba di Lapas}

Pemasyarakatan mempunyai fungsi untuk menyiapkan warga binanaanya dapat kembali diterima dan berinteraksi ditengah-tengah masyarakat. Karena biasaya ketika seorang narapidana telah masuk ke lapas, maka mereka akan merasa terasingkan setelah kembali ke masyarakat.

Narapidana tidak menjadi objek saja, tetapi juga menjadi subjek yang tidak berbeda dengan manusia pada umumnya yang sewaktu-watu bisa melakukan perbuatan yang dapat dipidanakan. Pemidanaan merupakan suatu upaya yang bertujuan untuk menyadarkan narapidana agar menyesali perbuatan yang sudah mereka lakukan dan dapat menjadi warga negara yang baik, mentaati hukum, memperhatikan nilai moral, sosial, maupun agama, sehingga akan mencapai kehidupan soaial yang aman, tentram dan damai. Berikut adalah merupakan program yang dapat diikuti narapidana pemakai narkoba selama menjalani masa pidananya di lembaga pemasyarakatan, yaitu:

1) Rehabilitasi medis

Program ini narapidana mendapat pemeriksaan kesehatan baik fisik maupun mental secara menyeluruh oleh dokter maupun perawat. Dam proses ini bertujuan untuk mengetahui seauh mana pengaruh zat-zat napza memberikan dampak negatif bagi kesehatan fisik dan mental narapidana. rahabilitasi ini dapat berupa Program Terapi Rumatan Metadone (PTMR) dan Terapi Complementer (Adiyanti, 2019). Program Terapi Rumatan Metadone (PTMR) merupakan bentuk partisipasi lapas dalam menjalankan kebijakan pemerintah. Program metadone adalah suatu terapi yang membantu para pecandu napza jenis heroin untuk melaukan kebiasaan baru, memperbaiki kualitas hidup bagi pengguna tanpa kekhawatiran terjadi gejala putus obat. Terpi complementer sendiri merupakan terapi tambahan dan penunjang yang tertumpu pada potensi diri seseorang (Afrizal \& Anggunsuri, 2019).

2) Rehabilitasi Non Medis

Pada tahap ini narapidana menjalankan salah satu program yaitu terapi rehabilitasi yang bertujuan untuk merubah perilaku narapidana yang tidak sesuai dengan peraturan atau norma yang ada di masyarakat (Fernanda, 2020). Pada terapi ini narapidana mendapat dukungan kelompok dan mendapatkan bimbingan serta pembelajaran tentang bagaimana bersikap tegas untuk meninggalkan serta menggunakan napza kembali. Salah satu program terapi non medis yaitu Therapeutic Community (TC), TC merupakan suatu program pemulihan yang membantu narapidana dalam pemulihan dan membantu merubah perilaku adiksi penyalahgunaan Napza menuju "Healthy Life Style" (gaya hudup yang sehat 
tanpa Napza). Terapi ini bertujuan untuk membantu seseorang atau narapidana untuk tidak melakukan kembali kejahatan.

3) Rehabilitasi afer care

Pada tahap ini narapidana diberikan kegiatan sesuai dengan minat dan bakat pada dirinya untuk mengisi kegiatan kesehariannya. Tujuan dari taham ini ialah untuk membekali para pecandu dengan pengetahuan dan keterampilan kemudian bisa diterapkan dalam kehidupam setelah kembali ke masyarakat. Dalam after care ada beberapa program yang disediakan, yaitu :

a. Pesantren terpadu

Program ini ini merupakan program pembinaan mental untuk narapidana guna mengembalikan nilai-nilai moral agama yang telah hilang, karena selama menjadi pecandu nilai-nilai spiritual mereka jauhi (Hakim, 2016).

b. Kursus bahasa inggris dan Komputer

Dalam program ini narapidana dibekali dengan keterampilan yang berguna bagi dan merupakan bagian penting dari program pembinaan di lapas. Keterampilan ini sangat membantu narapiana mencari pekerjaan setelah bebas nanti.

c. Kegiatan kerja

Kegiatan ini bertujuan untuk menggali dan memberdayakan potensi yang dimiliki oleh narapida dan lapas menyediakan beberapa kegiatan kerja yang bisa diikuti narapidana. diharapkan dengan adanya program ini narapidana dapat mengisi waktunya dengan kegiatan yang bermanfaat.

d. Kegiatan olahraga

Kegiatan ini dilaksanakan setiap hari sesuai jadwal yang sudah ditentukan oleh lapas. Program ini bertujuan untuk mengasah dan melatih bakat-bakat narapidana di bidang olahraga, sehingga mereka dapat menyalurkan bakat yang mereka miliki (Sholihah, 2015).

Jadi, upaya pembinaan terhadap narapidana pecandu narkoba adalah melalui program rehabilitasi, dan sebaiknya pemakai narkoba tidak ditempatkan di lapas. Tetapi realita yang ada dilapangan, baik pemakai, pengedar, dan bandar semuanya ditempatkan di lapas. Dalam hal ini pemakai adalah korban dan seharusnya direhabilitasi di panti rehabilitasi dan bukan dipidana di lapas. Hal ini dapat menimbulkan efek yang negatif, yang sebelumnya narapidana sebagai pemakai tetapi bergaul dengan pengedar sehingga kemungkinan akan mendapat intervensi dari narapidana lain.

Adanya program rehabilitasi di Indonesia sesuai dengan pasal 37 ayat (1) Undang-Undang Nomor 5 Tahun 1997 tentang Psikotropika yang menyebutkan bahwa "penggunaan psikotropika yang menderita sindrom ketergantungan berkewajiban ikut serta dalam pengobatan atau perawatan" (Presiden Republik Indonesia, 1997). Dalam pasal 45 Undang-Undang Nomor 22 Tahun 1997 tentang Narkotika yang menyebutkan "pecandu narkotika wajib menjalani pengobatan dan/atau perawatan" (Pemerintah Republik Indonesia, 1997). Lapas sebagai tempat 


\section{Afifudin Muhammad Yunus}

untuk membina warga binaan pemasyarakatan berfungsi sebagi tempat untuk terapi dan rehabilitasi bagi penyalahgunaan napza, sehingga melalui program ini diharapkan narapidana dapat kembali berperan aktif di masyarakat dala keadaan tidak ketergantungan lagi. Lapas diharapkan menjadi pelopor dan pusat penanggulangan terpadu pagi penyalahgunaan narkoba.

\section{Kesimpulan}

Narkoba merupakan barang yang berbahaya yang peredarannya dilarang oleh hukum. Menurut Pasal 1 angka 1 Undang-Undang Nomor 35 Tahun 2009 tentang Narkoba yang dilarang peredarannya. Pemberantasan Narkoba dilakukan dengan penekanan dari pegawai dengan disertai pengawasan yang berlapis kepada narapidana. sebelumnya petugas harus dibina sebelum membina narapidana, hal ini sangat penting guna menanamkan integritas dan meminimalisir peredaran narkoba di dalam lapas.

Metode rehabilitasi diharapkan dapat menjadi metode utama sebelum metode pemidanaan. Ada beberapa metode yang digunakan, yaitu: Rehabilitasi medis, rehabilitasi non medis dan rehabilitasi after care. Dengan adanya rehabiliasi diharapkan dapat memulihkan narapidana yang menjadi korban penggunaan narkoba. Pemisahan narapidana kasus narkoba dilakukan untuk menekan seminimal mungkin kemungkinan peredaran narkoba. Kerjasama antar instansi yang berkaitan dengan peredaran narkoba dibutuhka untuk menciptakan kondisi yang ideal dalam masyarakat. 


\section{BIBLIOGRAFI}

Absori, Kelik Wardiono, \& Rochman, Saepul. (2015). Hukum Profetik: Kritik Terhadap Paradigma Hukum Non-Sistematik. Yogyakarta: Genta Publishing.

Adiyanti, Maria Goretti. (2019). Inisiasi Ketangguhan Masyarakat dalam Mengatasi Adiksi NAPZA: Menelaah Program Rehabilitasi. Buletin Psikologi, 27(1), 87-108.

Afrizal, Riki, \& Anggunsuri, Upita. (2019). Optimalisasi Proses Asesmen terhadap Penyalah Guna Narkotika dalam Rangka Efektivitas Rehabilitasi Medis dan Sosial Bagi Pecandu Narkotika. Jurnal Penelitian Hukum De Jure, 19(3), 259-268.

Apriansyah, Nizar. (2017). Peningkatan Kemampuan Petugas Pemasyarakatan Dalam Menangulangi Peredaran Narkoba Di Lembaga Pemasyarakatan Dan Rumah Tahanan Negara (Development of Correctional Officer Competencies in Overcoming Drugs Trafficking at Correctional Institution and Detention Center). Jurnal Penelitian Hukum De Jure, 16(4), 395-409.

Arifin, Nurul. (2016). Jejak Freddy Budiman Gembong Narkoba yang Dihukum Mati. Retrieved from Oke News. website: https://nasional.okezone.com/read/2016/07/29/ 337/1449561/jejak-freddy-budiman-gembong-narkoba-yang-dihukum-mati

Fernanda, Farrin Rizki. (2020). Efektivitas Pelaksanaan Rehabilitasi Sosial Terhadap Warga Binaan Pemasyarakatan Di Lembaga Pemasyarakatan Narkotika Kelas IIA Lubuk Linggau. Syntax Literate; Jurnal Ilmiah Indonesia, 5(9), 824-832.

Hakim, M. Arief. (2016). Bahaya Narkoba Alkohol: Cara Islam Mengatasi, Mencegah Dan Melawan. Bandung: Nuansa Cendekia.

Indonesia, Pemerintah Republik. (1997). Undang-Undang No. 22 Tahun 1997, tentang Narkotika. Jakarta: DPR RI.

Indonesia, Presiden Republik. (1997). Undang-Undang Nomor 5 Tahun 1997 Tentang Psikotropika. Jakarta: Presiden Republik Indonesia.

Lestari, Sri. (2017). Bisakah Menghentikan Peredaran Narkoba Di Dan Dari Penjara? Retrieved September 28, 2020, from BBC News | Indonesia website: https://www.bbc.com/indonesia/indonesia-40806642

Lexy, J. Moleong. (2005). Metode Penelitian Kualitatif. Bandung: Rosda Karya.

Purnamasari, Dinda. (2017). Krisis Rutan dan Lapas di Indonesia. Retrieved September 20, 2020, from Tirto.id website: https://tirto.id/krisis-rutan-dan-lapas-di-indonesiacr87

Sholihah, Qomariyatus. (2015). Efektivitas Program P4GN terhadap Pencegahan Penyalahgunaan NAPZA. KEMAS: Jurnal Kesehatan Masyarakat, 10(2), 153159. 
Afifudin Muhammad Yunus

Supriyadi, Supriyadi. (2016). Community of Practitioners: Solusi Alternatif Berbagi Pengetahuan antar Pustakawan. Lentera Pustaka: Jurnal Kajian Ilmu Perpustakaan, Informasi Dan Kearsipan, 2(2), 83-93.

V. H.Situmorang, HAM, R., \& Kav, J. H. R. S. (2019). Lembaga Pemasyarakatan sebagai Bagian dari Penegakan Hukum. Jurnal Ilmiah, 13(1), 85-98.

Vaulamafiroh, Dayang. (2020). Penerapan Peraturan Menteri Hukum dan Hak Asasi Manusia Nomor 6 Tahun 2013 Tentang Tata Tertib Lembaga Pemasyarakatan dan Rumah Tahanan Perspektif Hukum Pidana Islam (Studi Kasus Di Lembaga Pemasyarakatan Perempuan Klas II A Palembang). Palembang: UIN Raden Fatah Palembang. 